\title{
Pengembangan Pola Pikir Rasional dan Objektif dalam Pembelajaran IPA melalui Pendekatan Scientific
}

\author{
Muhammad Yudi Susanto1), Asih Dwi Mumpuni'2), Ika Nur Fadhilah ${ }^{3)}$ \\ 1,2,3)Fakultas Keguruan dan Ilmu Pendidikan \\ Universitas Muhammadiyah Surakarta \\ a420170073@student.ums.ac.id \\ doi: $\mathrm{xxx}$ xxx xxx
}

\begin{abstract}
Abstrak: Upaya dalam meningkatkan pendidikan tidak lepas dari pengaruh guru dan siswa di dalam proses pembelajaran. Guru adalah komponen yang sangat berpengaruh terhadap proses belajar. Siswa juga merupakan subjek di dalam pembelajaran, maka dari itu keduanya merupakan komponen yang penting. Penelitian ini dilakukan di SMP Negeri 2 Kartasura dengan subjeknya berupa pelaksana kegiatan pembelajaran yaitu guru dan siswa. Fokus penelitian pada penggunaan metode pendekatan scientific di dalam proses pembelajaran yaitu dengan cara mengamati, menanya, mencoba, mengasosiasi, dan mengkomunikasikan untuk mengembangkan pola berpikir rasional dan objektif. Pembelajaran IPA Terpadu merupakan salah satu pembelajaran yang mengacu pada aspek berpikir yang rasional dan objektif. Hal itu disebabkan karena di dalamnya terdapat tahapan yang mendorong siswa untuk berpikir secara ilmiah. Pembelajaran IPA Terpadu yang terdiri tiga disiplin ilmu yaitu, ilmu biologi, ilmu kimia, dan ilmu fisika perlu pemahaman yang matang. Jadi, untuk meningkatkan hasil belajar harus ada kaitan antara komponen guru, siswa, metode/pendekatan dan materi pembelajaran.
\end{abstract}

Kata kunci : Guru dan Siswa, Pendekatan Scientific, Pembelajaran IPA Terpadu, Berpikir Rasional dan Objektif.

\section{Pendahuluan}

Pembelajaran IPA merupakan suatu pembelajaran ilmu pengetahuan yang terdiri dari 3 disiplin ilmu, ilmu biologi, ilmu fisika dan ilmu kimia (Widiyatmoko, 2013). Ketiga rumpun ilmu tersebut yang dikenal dengan mata pelajaran IPA, biasanya berada dalam jenjang sekolah menengah pertama. Guru biasanya menerapkan suatu metode/pendekatan untuk merealisasikan proses pembelajaran. Pendekatan scientific merupakan salah satu pendekatan yang digunakan dalam pembelajaran IPA karena pembelajaran IPA lebih menekankan berpikir ilmiah (sikap sains) dalam suatu pemahaman dan penalaran. Pendekatan scientific merupakan pendekatan pembelajaran dengan suatu proses mengamati, menanya, mencoba, mengasosiasi, dan mengkomunikasikan (Katimo, 2016). Jika pembelajaran IPA diterapkan melalui pendekatan scientific, maka dapat mengembangkan pola berpikir rasional dan objektif. Hal tersebut dikarenakan materi IPA berhubungan erat dengan berpikir rasional (masuk akal) dan objektif (apa adanya).

Pembelajaran IPA memerlukan suatu sikap ilmiah dan sains 


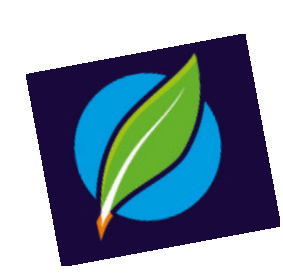

dalam implementasinya. Oleh karena itu dengan adanya pendekatan scientific dapat membantu siswa dalam mengembangkan pola pikir yang mengarah pada rasional dan objektif, dengan cara peserta didik diarahkan untuk berpikir secara ilmiah pada suatu pembelajaran melalui proses mengamati suatu objek pengamatan kemudian mencoba, menyimpulkan dan merealisakan. Jadi peserta didik bukan hanya terpaku pada suatu teori, namun mengetahui realisasi ilmu di dalam kehidupan. Kemendikbud No. 65 Tahun 2013 tentang Standar Proses Pendidikan Dasar dan Menengah telah mengisyaratkan tentang perlunya proses pembelajaran yang dipandu dengan kaidahkaidah pendekatan saintifik atau ilmiah, karena dalam pelaksanaan pembelajaran terdapat 3 tahapan yaitu adanya kegiatan pendahuluan, kegiatan inti dan kegiatan penutup (Susilo, 2016). Hal ini dapat mengembangkan cara pola berkir peserta didik yang awalnya hanya mengandalkan teori yang terpaku pada suatu buku, namun peserta didik dapat berpikir secara rasional dan objektif melalui suatu eksperimen (praktikum). Jadi peserta didik dituntut untuk mereliasasikan ilmu teori yang didapat dan dipraktekkan secara lansung dengan pendekatan scientific. Jadi pendekatan scientific sangat cocok jika dikaitkan erat dengan pembelajaran IPA.

Pembelajaran IPA bukan hanya mengandalkan suatu teori, namun real dalam kehidupan. Ilmu dalam pembelajaran IPA erat kaitannya dengan ilmu pengetahuan alam yang erat hubungannya dengan realisasi dalam kehidupan. Jika ini dapat terealisasikan maka pembelajaran IPA melalui pendekatan scientific dapat mengembangkan peserta didik dalam mengembangkan pola berpikir secara rasional (masuk akal) dan objektif (secara real). Siswa akan lebih mudah dalam memahami suatu materi yang didapatkan karena dapat mempraktekkan ilmu secara langsung. Oleh karena itu, pendekatan scientific sangat cocok jika diterapkan di dalam suatu pembelajaran terutama dalam pembelajaran IPA. Peserta didik dapat diajarkan cara berpikir rasional (masuk akal) dan objektif, sehingga pola berpikir peserta didik dapat berkembang dengan pola tersebut melalui pendekatan scientific.

Adapun tujuan yang ingin dicapai dari penelitian ini yaitu: (1) Mengetahui pendekatan scientific dapat mengembangkan pola berpikir secara rasional dan objektif. (2) Mengetahui langkahlangkah pendekatan scientific dalam mengembangkan pola berpikir secara rasional dan objektif. (3) Mengetahui cara mengembangkan pola berpikir rasional dan objektif dalam pembelajaran IPA Terpadu.

\section{Metode}

Jenis penelitian yang digunakan dalam penelitian ini adalah penelitian kualitatif, yaitu penelitian yang memiliki dasar deskriptif guna memahami suatu fenomena dengan lebih mendalam. Penelitian 


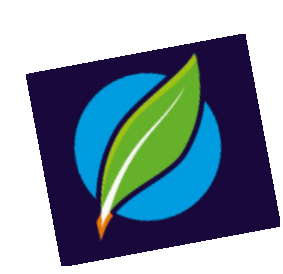

kualitatif menggunakan landasan teori sebagai panduan untuk memfokuskan penelitian, serta menonjolkan proses dan makna yang terdapat dalam fenomena tersebut. Dalam penelitian ini, data yang dihimpun berupa data primer dan data sekunder. Data primer merupakan data observasi, survey, atau wawancara dari narasumber atau objek penelitian, sedangkan data sekunder adalah berupa data dokumentasi.

Lokasi penelitian yang dilakukan adalah di SMP Negeri 2 Kartasura, dengan waktu dilakukannya penelitian adalah mulai dari tanggal 29 Januari sampai tanggal 11 Februari 2019. Subyek dari penelitian ini adalah siswa kelas VII A dan kelas VIII F SMP Negeri 2 Kartasura. Sedangkan objek penelitian ini adalah pelaksanaan kegiatan pembelajaran IPA terpadu dengan menerapkan metode pembelajaran yang menarik siswa.

Pengumpulan data yang digunakan dalam pelaksanaan pemebelajaran biologi adalah observasi (pengamatan), dokumentasi, dan wawancara. Teknik observasi (pengamatan) dilakukan di kelas VII A dan VIII F. Durasi observasi dilakukan selama 2 jam pelajaran untuk setiap kelas yang diamati pada mata pelajaran IPA Terpadu. Pada kelas VII A dilakukan observasi mengenai pembelajaran ilmu biologi. Sedangkan pada kelas VIII F dilakukan observasi dengan materi pembelajaran ilmu fisika dan ilmu biologi. Observasi (pengamatan) dilakukan untuk mengamati mengenai kegiatan pembelajaran, suasana/kondisi kelas waktu kegiatan pembelajaran, metode mengajar oleh guru, materi pembelajaran dan interaksi antara siswa dengan guru.

Pengumpulan data selanjutnya dengan teknik dokumentasi. Dokumentasi dapat membantu dalam pengumpulan data yang relevan dan sebagai data pendukung dalam penelitian. Dokumentasi dilakukan sewaktu penelitian dilakukan didalam pelaksanaan pembelajaran kelas. Kemudian teknik wawancara yaitu dengan jenis wawancara semi berstruktur. Wawancara ini dimulai dari isu yang dicakup dalam penelitian. Wawancara dilakukan dengan cara memberi beberapa pertanyaan mengenai proses pembelajaran di kelas yang menggunakan kurikulum 2013 kepada Ibu Sri salah seorang guru IPA Terpadu. Wawancara dilakukan ketika bel pulang sekolah berbunyi di ruang guru.

Data-data yang telah didapatkan kemudian dianalisis dan dijabarkan dalam bentuk deskripsi pada hasil dan pembahasan penelitian. Analisis data dilakukan secara deskriptif yang bertujuan untuk memberikan gambaran tentang keterlaksanaan pembelajaran IPA Biologi dengan saintific approach yang selanjutnya dihitung persentase dan dikonversi dengan standar acuan dari (Susilo, 2016).

\section{Hasil dan Pembahasan}

Berdasarkan observasi SMP Negeri 2 Kartasura telah 


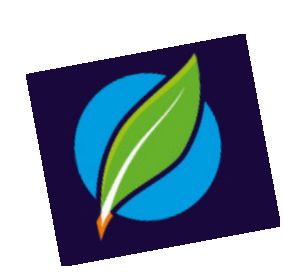

menerapkan kurikulum 2013 sejak dua periode terakhir yaitu pada kelas VII dan VIII. Prinsip- prinsip kegiatan pembelajaran yang diatur dalam Permendikbud No. 81A Tahun 2013 tentang Implementasi Kurikulum 2013 yaitu: (1) berpusat pada peserta didik; (2) mengembangkan kreativitas peserta didik; (3) menciptakan kondisi menyenangkan dan menantang; (4) bermuatan nilai, etika, estetika, logika, dan kinestetika; (5) menyediakan pengalaman belajar yang beragam melalui penerapan berbagai strategi dan metode pembelajaran yang menyenangkan, kontekstual, efektif, efisien, dan bermakna yang dikembangkan dalam sains adalah sikap ilmiah yang dikenal dengan scientific attitude. Dari hasil observasi pada saat proses pembelajaran berlangsung terdapat beberapa metode mengajar yaitu: (1) metode ceramah; (2) metode tanya jawab; (3) metode diskusi; (4) metode eksperimen; (5) metode tugas dan resitasi; (6) metode presentasi. Metode ceramah masih digunakan dalam proses pembelajaran bersamaan dengan metode lain meskipun kurikulum kurikulum 2013 telah diterapkan.

Pendekatan scientific merupakan suatu proses pembelajaran dengan cara mengamati, menanya, mencoba, mengasosiasi, dan mengkomunikasikan. Pembelajaran IPA salah satu pembelajaran yang menerapkan sikap sains (ilmiah), sehingga pendekatan scientific salah cocok diterapkan di dalam suatu pembelajaran IPA. Penerapan pendekatan scientific di dalam suatu pembelajaran IPA direalisasikan dengan suatu kegiatan eksperimen (percobaan/praktikum). IPA terbagi dalam 3 disiplin ilmu, biologi, kimia dan fisika. Ketiga ilmu tersebut memerlukan pemahaman dan penalaran dalam proses berpikirnya. Dalam jenjang sekolah menengah pertama masih dikategorikan dalam satu pembelajaran IPA namun peserta didik dituntut untuk lebih kritis dalam pemahaman dan penalarannya.

Indikator pencapaian di dalam suatu proses pembelajaran IPA melalui pendekatan scientific, yaitu

1. Peserta didik dapat memahami pembelajaran IPA bukan hanya dari segi teori namun juga dari segi praktik

2. Peserta didik dapat mengembangkan pola berpikir secara rasional dan objektif

3. Peserta didik dapat menyelesaikan permasalahan di dalam suatu pembelajaran

4. Peserta didik dapat menunjukan sikap kerja sama, minat, tanggung jawab sera komitmen dalam melaksanakan tugas yang telah ditentukan

Implementasi kurikulum 2013 dapat terlihat pada metode yang menjadikan siswa sebagai student of center. Pendekatan scientific adalah pendekatan yang wajib digunakan pada pembelajaran di sekolah berdasarkan aturan kurikulum 2013. Langkah-langkah pada pendekatan saintifik merupakan adaptasi dari langkah-langkah ilmiah pada sains. Mata pelajaran IPA Terpadu termasuk ke dalam 


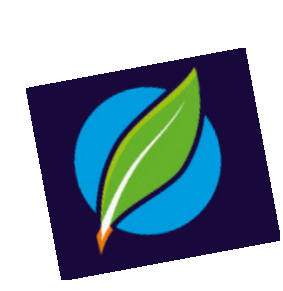

rumpun sains yang di dalamnya terdapat ilmu fisika, ilmu biologi, dan ilmu kimia yang merupakan satu kesatuan atau tidak terpisahkan. Pembelajaran dengan pendekatan saintifik adalah proses pembelajaran yang dirancang sedemikian rupa agar peserta didik secara aktif mengonstruk konsep, hukum atau prinsip melalui tahapan-tahapan mengamati (untuk mengidentifikasi atau menemukan masalah), merumuskan masalah, mengajukan atau merumuskan hipotesis, mengumpulkan data dengan berbagai teknik, menganalisis data, menarik kesimpulan dan mengomunikasikan konsep, hukum atau prinsip yang "ditemukan" (Sufairoh, 2016).

\section{SMP NEGERI 2 KARTASURA}

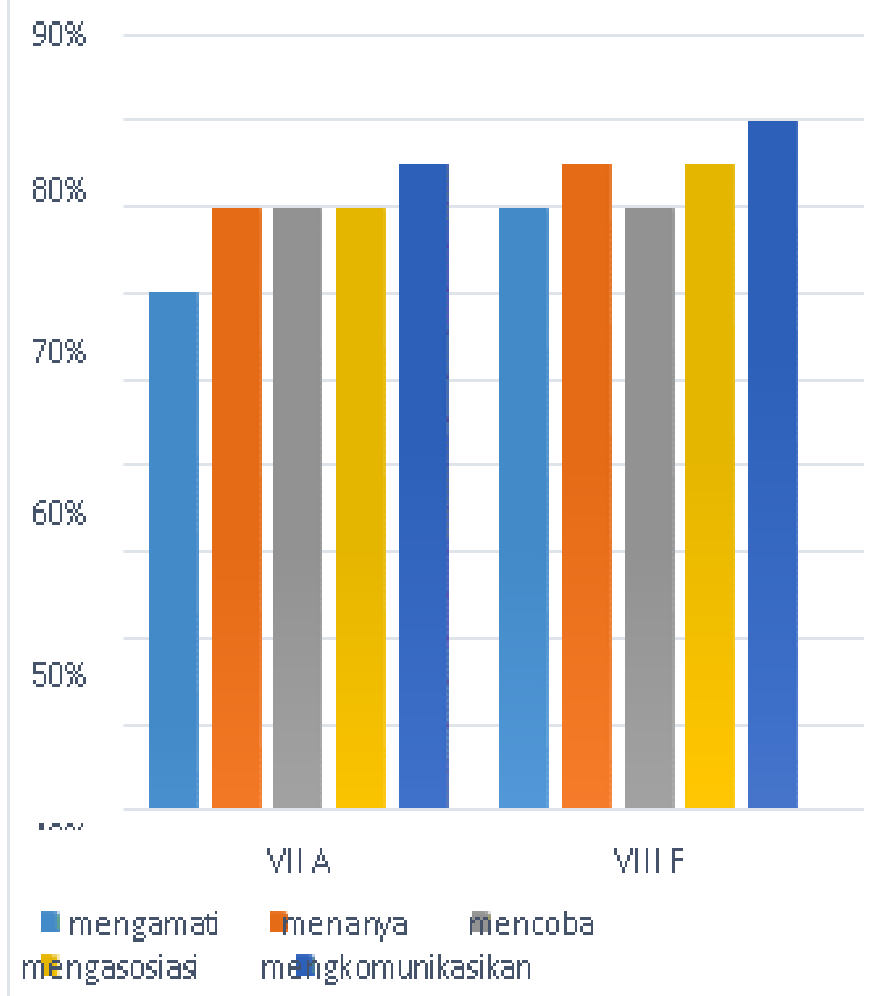

Gambar 1. Persentase Pelaksanaan Pendekatan Scientific

Pembelajaran IPA Terpadu di kelas VIII F dengan menerapkan pendekatan scientific mengenai materi bab pernafasan pada manusia dengan menghitung jumlah frekuensi pernafasan. Sebelum melakukan diskusi, mereka melakukan percobaan terlebih dahulu. Di dalam metode ini terdapat tahapan ilmiah yaitu mengamati jumlah bernafas dalam waktu 1 menit selama tiga kali ulangan, mencoba melakukannya dengan menghitung menggunakan arloji selama 1 menit, mengumpulkan data frekuensi pernafasan sendiri dan dua orang temannya dalam bentuk tabel, mendiskusikannya bersama, menganalisis data dengan menghitung rata-rata frekuensi 


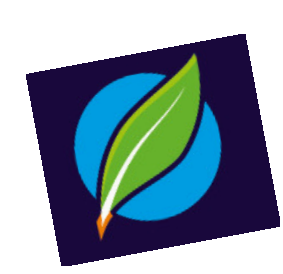

pernafasan dan membandingkan dengan rata-rata frekuensi pernafasan dua orang teman yang lain. Pengisian data dalam tabel tersebut yang sesuai dengan hasil pengamatan melatih siswa berpikir secara objektif, jujur, dan dapat dipertanggungjawabkan. Peserta didik secara aktif bertanya selama pembelajaran berlangsung, sesuatu yang mereka tidak ketahui. Setelah itu dilanjutkan menjawab soal diskusi mengenai faktor yang mempengaruhi perbedaan frekuensi pernafasan tersebut. Dari segi mengamati- 70\%, menanya-75\%, mencoba-70\%, mengasosiasi-75\% dan mengkomunikasikan- $80 \%$. Hal rasio dalalam hal mengkomunikasikan atau interaksi siswa lebih besar dari yang lainnya. Dalam hal ini terjadi interaksi aktif antara siswa dengan siswa yang mulai berpikir secara rasional atau masuk akal mengenai jawaban soal diskusi.

Di sisi lain berdasarkan observasi di kelas VII A, peserta didik di dalam suatu proses pembelajaran mengenai rantai makanan pada bab ekosistem melakukan dengan cara mengamati mengenai rantai makanan dalam suatu ekosistem kemudian mencoba melakukan rangkaian dari rantai makanan tersebut secara kelompok dan mendiskusikan. Peserta didik banyak secara aktif bertanya mengenai sesuatu yang dianggap belum diketahuiinya kepada guru, sehingga dapat menimbulkan interaksi yang aktif antaara keduanya. Salah satu kelompok dari mereka mempresentasikan hasil diskusinya di depan kelas. Setelah melakukan presentasi, banyak siswa yang aktif menyempurnakan hasil diskusi kelompok tersebut. Dilihat dari segi hasilnya, mengamati-60\%, menanya-70\%, mencoba-70\%, mengasosiasi-70\% dan mengkomunikasikan-75\%. Dalam hal ini siswa dilatih mengembangkan pola berpikir rasional dengan cara menyempurnakan hasil diskusi yang dapat dipertanggungjawabkan mengenai jawaban diskusi tersebut yang masuk akal atau tidak, sehingga dapat melatih berpikir peserta didik.

Observasi yang telah dilakukan pada kedua kelas menunjukkan siswa berperan aktif dengan metode yang menjadikan siswa sebagai pusat pembelajaran. Terjadi interaksi timbal balik antara siswa dengan siswa maupun siswa dengan guru. Berbeda halnya ketika menggunakan metode guru sebagai pusat pembelajaran yang siswa cenderung diam dan mengantuk tidak ada kegiatan yang menantang atau dapat mengembangkan keaktifan siswa mngenai pola berpikir siswa yang rasional dan objektif.

\section{Simpulan}

Dari hasil observasi dan wawancara dapat disimpulkan bahwa pendekatan saintifik dapat mengembangkan pola berpikir rasional dan objektif. Pengembangan pola berpikir rasional dan objektif tersebut dapat dilatih melalui proses pembelajaran dengan metode pembelajaran yang menggunakan tahapan ilmiah yaitu mengamati, mengumpulkan data, menentukan hipotesis, menganalisis data, 
menarik kesimpulan, mengkomunikasikan hal yang telah didapatkan. Dalam pembelajaran IPA Terpadu tidak lepas dari tahapan ilmiah yang ada dalam sains. Hal itu dapat diimplementasikan ke dalam percobaan-percobaan mengenai materi terkait yang di dalamnya terdapat tahapan ilmiah sehingga dapat mengembangkan pola berpikir secara rasional dan objektif pada siswa yang secara aktif dan langsung melakukan percobaan tersebut sehingga mendaoatkan pengalaman secara langsung dan pembelajaran menjadi lebih bermakna.

\section{Daftar Pustaka}

Katimo, S. S. (2016). Pengaruh Pembelajaran Dengan Pendekatan Saintifik Menggunakan Metode Eksperimen Dan Demonstrasi Terhadap Prestasi Belajar Dan Kreativitas Ditinjau Dari Sikap Ilmiah. Jurnal Inkuiri, Vol :5(No:2), hal : 87-89.

Sufairoh. (2016). Pendekatan Saintifik dan Model Pembelajaran K-13. Jurnal Pendidikan Profesional, Vol : 5(No : 3), Hal : 120-121.

Susilo, M. J. (2016). Pembelajaran IPA Biologi Berbasis Scientific Approach Di SMP Muhammadiyah 2 Depok Sleman. Proceding Biology Education Conference, Vol :13(No: 1), hal : 1 .

Widiyatmoko, B. P. (2013). Pengembangan LKS IPA Terpadu Berbasis Inkuiri Tema Darah di SMP N 2 Tengaran. Jurnal Pendidikan IPA Indonesia, Vol :2(No : 2), Hal : 103 . 